\title{
Interpreting the Politics of the Judiciary: The British Senior Judicial Tradition and the Pre-emptive Turn in Criminal Justice
}

\author{
Harry Annison, School of Law, University of Southampton, UK
}

Post-acceptance version

The final, definitive version of this paper has been published in the Journal of Law and Society (2014) 41 (3) 339-366 by Blackwell Synergy, All Rights Reserved. (C Harry Annison

The definitive version is available at www.blackwell-synergy.com

http://dx.doi.org/10.1111/j.1467-6478.2014.00673.x 


\title{
Interpreting the Politics of the Judiciary: The British Senior Judicial Tradition and the Pre-emptive Turn in Criminal Justice
}

\author{
HARRY ANNISON*
}

\begin{abstract}
This article presents an interpretive politics of the judiciary, arguing for the value of interpretive political analysis in understanding developments in case law and judicial activity. It sketches out a senior judicial tradition, which is argued to guide but not predetermine the actions of the British senior judiciary. A case study, the senior judiciary's response to the Imprisonment for Public Protection (IPP) sentence, is presented which draws on case law, extra-judicial speeches and interviews with five relevant serving or retired senior judges. It is argued that this case study demonstrates the senior judiciary to be politically attuned actors, often highly sensitive to the broader context in which their judgments sit, while equally being determined to act with fidelity to the law and the responsibilities inherent in membership of an independent, impartial judiciary. In closing, it is argued that the IPP case law suggests that the senior judicial tradition, and its inherent tensions, limits the extent to which the senior judiciary feel equipped to oppose the 'preemptive turn' in criminal justice.
\end{abstract}

Over the past fifty years, scholars such as John Griffith, ${ }^{1}$ Alan Paterson ${ }^{2}$ and David Robertson $^{3}$ have dismantled the longstanding orthodoxy that the judiciary engage in neither policymaking nor politics. This article proceeds from an acceptance of Griffith's central claim that judges are political actors, in the sense that as 'part of the machinery of authority within the State...[they] cannot avoid the making of political decisions'. ${ }^{4}$ Indeed, the case study presented below is argued to demonstrate that the British senior judiciary are thoughtful participants in British politics, seeking to affect the course taken by criminal justice and sentencing policy.

This article draws upon the work of Mark Bevir and Rod Rhodes ${ }^{5}$ to propose an interpretive politics of the judiciary; a theoretical and methodological framework which is capable of respecting British judges' genuine fidelity to the law, while recognising their role as political actors. Interpretive approaches encourage us to explore the nature and influence of meanings, beliefs and practices. We are compelled to take seriously the ways in which political actors 'make sense of their world."

\footnotetext{
* School of Law, Southampton University, Highfield, Southampton SO17 1BJ

h.annison@soton.ac.uk
}

This work was supported by an Economic and Social Research Council 1+3 Studentship [grant ES/GO10307/1]. I am grateful to Ian Loader, Nicola Lacey, Lucia Zedner, Andrew Ashworth, Zelia Gallo, participants at the ESC Working Group on Sentencing and Penal Decision-Making, September 2013, and the anonymous referees for comments on an earlier draft.

\footnotetext{
${ }^{1}$ J. A. G. Griffith, The Politics of the Judiciary (1997).

${ }^{2}$ A. Paterson, The Law Lords (1982).

${ }^{3}$ D. Robertson, Judicial Discretion in the House of Lords (1998).

${ }^{4}$ Griffith, op. cit. n. 1, p. 293.

${ }^{5}$ M. Bevir and R.A.W. Rhodes, Interpreting British Governance (2003).

${ }^{6}$ R.A.W. Rhodes, Everyday Life in British Government (2011) 17.
} 
This article sketches a senior judicial tradition (SJT), 'a set of theories, stories, and associated practices people inherit that then forms the background against which they hold beliefs and perform actions'. 'It is argued that this tradition promotes 'responsible' behaviour, seeking to shore up existing administrative systems and to maintain the standing of the senior judiciary. ${ }^{8}$ However, it can be seen to legitimize, to a limited extent, judicial efforts to mitigate 'bad law'. ${ }^{9}$ While encroachment into the policymaking arena is approached with extreme caution, ${ }^{10}$ it is not entirely illegitimate.

The legal judgments relating to the Imprisonment for Public Protection (IPP) sentence are then explored through this interpretive lens. The coherence of the case law - oriented around two central issues and involving the High Court, Court of Appeal and House of Lords - is one factor which makes this a valuable case study. A second is the access obtained to members of the senior judiciary: this article draws on inter alia interviews conducted with five relevant serving or retired senior judges. This case study is argued to show relevant members of the senior judiciary to be careful, responsible and reflective political actors.

The judicial responses to the dilemmas posed by the IPP sentence are explored, and the relationship between these responses and the SJT discussed. We see that the judgments and other judicial activity were motivated by concerns that the IPP sentence was disproportionate, liable to lead to injustice in individual cases and to cause significant problems for the penal system. However, as the cases progressed up the judicial hierarchy, we see that these concerns became increasingly subsumed by the elements of the SJT promoting caution and restraint.

In closing, these findings are connected to writings on the 'pre-emptive turn' in criminal justice. ${ }^{11}$ It is argued that the inherent tensions within the SJT - and not least its valorisation of stability and restraint - mean that, in a political climate where insecurity and risk aversion have become pervasive, ${ }^{12}$ the British senior judiciary stand ill-equipped to contest robustly, and in their eyes legitimately, particular instances of this concerning trend.

\section{TOWARDS AN INTERPRETIVE POLITICS OF THE JUDICIARY}

We can begin setting out an interpretive politics of the judiciary by noting the points of accord and dissonance with three prominent works on senior judicial activity: Paterson's The Law Lords, ${ }^{13}$ Robertson's Judicial Discretion in the House of Lords ${ }^{14}$ and Griffith's The Politics of the Judiciary. ${ }^{15}$ These valuable works have contributed to an increasing

\footnotetext{
${ }^{7}$ M. Bevir, 'Interpretive Theory' in The SAGE Handbook of Governance, ed. Mark Bevir (2010) 58.

${ }^{8}$ A. Gearey et al., The Politics of the Common Law (2009) 77; Robertson, op. cit. n.3, p.400.

${ }^{9}$ N. G. Fielding, 'Judges and Their Work' (2011) 20 Social \& Legal Studies 1.

${ }^{10}$ K.D. Ewing, 'Judiciary' in The Oxford Handbook of British Politics, ed. M. Flinders et al. (2009); Gearey et al, op. cit. n.8, p.91; Griffith, op. cit. n.1.

${ }^{11}$ L. Zedner, 'Fixing the Future? The pre-emptive turn in criminal justice' in Regulating Deviance, ed. B. McSherry et al. (2009).

${ }^{12}$ R. V. Ericson, Crime in an Insecure World (2006).

${ }^{13}$ Paterson, op. cit. n. 2.

${ }^{14}$ Robertson, op. cit. n. 3.

${ }^{15}$ Griffith, op. cit. n. 1.
} 
acceptance that 'judges are active policy-makers', ${ }^{16}$ as Gearey and colleagues have put it, 'judges are political and that it is better to have openness about the politics of their role.' 17

Alan Paterson promoted a social interactionist approach, arguing that 'decisionmaking in the House of Lords should be seen as a social process...The printed speeches are but the end product of a complex series of exchanges between Bar and Bench and between the Law Lords themselves. ${ }^{18}$ The interpretive politics of the judiciary set out below recognises the important role played by social interaction, but considers a focus on activity within the courtroom as to be unnecessarily limited, if our goal is to understand judicial activity in the round. ${ }^{19}$

David Robertson furthered a legal realist argument in Judicial Discretion in the House of Lords. ${ }^{20} \mathrm{He}$ argued that the freedom enjoyed by the judiciary in engaging in the interpretation of statute and preceding cases is far greater than is commonly understood, ${ }^{21}$ and that 'taking judicial decisions to be largely unconstrained policy preferences, is a valid interpretation of the higher English courts'. ${ }^{22}$ On this view, concepts such as Wednesbury unreasonableness are merely 'code-phrases', telling the judge 'how to enunciate what he has decided, what code language to use. ${ }^{23}$

The interpretive politics of the judiciary shares Robertson's scepticism towards explanations of judicial outcomes which leave little room for human agency. However, it rejects a view of senior judicial actors as duplicitous; they may often have scope to decide a case either way, but they are heavily constrained by their own understanding of the behaviour expected of members of the senior judiciary.

JAG Griffith's The Politics of the Judiciary, ${ }^{24}$ first published in 1977, offered an analysis which absolved judges 'of a conscious and deliberate intention to pursue their own interests or the interests of their class. ${ }^{25}$ Rather, Griffith argued that because of their shared educational experiences, shared training and experience at the Bar and their shared social situation as members of the 'Establishment', senior British judges share an inherently conservative (as distinct from a Conservative) understanding of the public interest. ${ }^{26}$ On this view, the senior judiciary were therefore structurally biased against 'progressive' political agendas.

The interpretive politics of the judiciary rejects class-based analysis on the basis that such a perspective denies the creative potential held by all individuals. It risks slipping into a deterministic narrative which leaves us with little understanding of how the activities or beliefs of particular individuals or groups have changed over time, or indeed may change in

\footnotetext{
${ }^{16}$ K. Malleson, The New Judiciary (1999) 35.

${ }^{17}$ Gearey, op. cit. n. 8, p. 136.

${ }^{18}$ Paterson, op. cit. n. 2, p. 8.

${ }^{19}$ Paterson has recognized this himself: A. Paterson, Final Judgment (2013), ch. 7.

${ }^{20}$ Robertson, op. cit. n.3. For discussion of the legal realist movement in the United States, see K. Llewellyn, Jurisprudence (1962).

${ }^{21}$ Related to this is Tata's argument that rules and discretion are not distinct, but exercised simultaneously. Thus a decision to merely apply the law, by identification of the 'one right answer', is itself a discretionary choice: C. Tata, 'Sentencing as Craftwork and the Binary Epistemologies of the Discretionary Decision Process' (2007) 16 Social \& Legal Studies 3.

${ }^{22}$ Robertson, op. cit. n. 3, p. 70.

${ }^{23}$ Robertson, op. cit. n. 3, p. 239.

${ }^{24}$ Griffith, op. cit. n. 1.

25 id., p. 334.

26 id., p. 295.
} 
the future. Against this background, the specific features of the interpretive politics of the judiciary can now be set out.

\section{An Interpretive Politics of the Judiciary}

This interpretive perspective understands change to arise:

As situated agents respond to novel ideas or problems. [It] is a result of people's ability to adopt beliefs and perform actions through a reasoning that is embedded in the tradition they inherit. ${ }^{27}$

We can unpack this statement, and thus illuminate the key components of the interpretive political analysis approach of Bevir and Rhodes which underpins it, by considering in turn the central concepts of 'agency', 'beliefs', 'traditions' and 'dilemmas'.

Reference to 'situated agents' points to a conception of actors who, though unable to 'escape from all social influences' - they are not fully autonomous subjects - are capable of acting 'creatively for reasons that make sense to them'. ${ }^{28}$ They 'always start against a social background that influences them but they can reason and act in novel ways to alter this background. ${ }^{29}$

In acting, individuals draw upon beliefs and traditions. 'Beliefs' are

Not just big commitments people reach through deliberate reflection.

They include the everyday tacit understandings on which people act without any noticeable deliberation. ${ }^{30}$

They are the meanings by which actors construct their world; they condition their understandings of the rules, conventions and institutional procedures which they encounter. ${ }^{31}$

'Traditions' are 'a set of connected beliefs and habits that intentionally or unintentionally passed from generation to generation at some point in the past'. ${ }^{32}$ For Bevir and Rhodes, 'Traditions are not fixed entities... They are contingent, produced by the actions of individuals. The carriers of a tradition bring it to life.' ${ }^{33}$

The common understandings which comprise traditions make 'possible common practices and a widely shared sense of legitimacy. ${ }^{34}$ In this present context, it is important to note that such traditions relate not only to the judiciary's perception of the legitimacy of the law's content, ${ }^{35}$ but also on the perceived extent and limits of the boundaries of legitimate judicial activity. ${ }^{36}$ By acting, the senior judiciary address, more or less explicitly, issues such as the appropriate relationship between the senior judiciary and the executive, the extent to

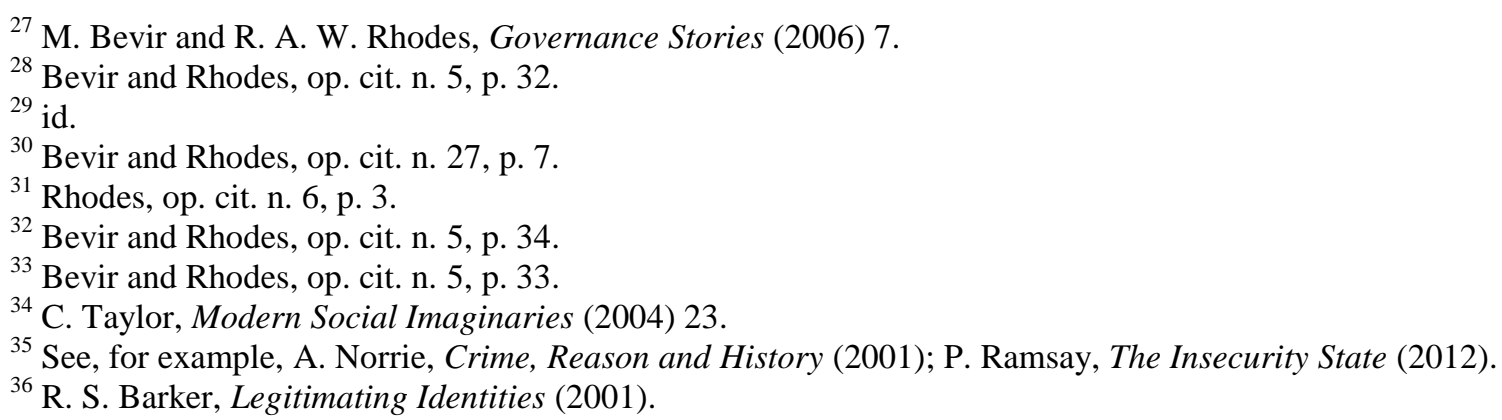


which judges should adopt an 'activist' role and what it means for them to act in the 'public interest'.

Change occurs when actors are faced with a 'dilemma'. Dilemmas arise 'when a new belief, often itself an interpretation of an experience, stands in opposition to their existing ones, thereby forcing a reconsideration of the latter. ${ }^{37}$ Dilemmas are not, in a straightforward sense, 'objective pressures in the world'. ${ }^{38}$ Rather, they denote the pressures and challenges perceived to be true by relevant actors. They can 'arise from both theoretical and moral reflection and from experiences of worldly pressures. ${ }^{39}$ Examples include the 'dilemma posed by the increasing size and scale of government, ${ }^{40}$ or the impact of globalization upon economic policy. ${ }^{41}$

The foregoing discussion should not be taken to argue that external constraints do not exist. However, an interpretive approach does understand actors often to be less constrained than they consider themselves to be. For example, actions taken by many nation states in the face of the perceived external constraints imposed by globalization can be understood to have entrenched the very 'objective conditions' on which the actions were originally predicated. ${ }^{42}$

We should note that:

dilemmas do not have given, nor even correct, solutions...individuals necessarily change traditions in what is a creative process. A tradition may appear to tell people how they should extend it, modify it, or apply it. However, it can only provide them with a guide to what they might do. ${ }^{43}$

In an observation which resonates with Paterson's observations on the importance of the 'complex series of exchanges between Bar and Bench and between the Law Lords themselves', 44 'the only way [actors] have of checking whether their response [to a particular dilemma] has been true to [a particular] tradition is to ask whether they and others are happy with it. ${ }^{45}$ To remain meaningful, traditions must have a degree of coherence; thus 'people can integrate a new belief into their existing beliefs only by relating themes in it to themes already present in their beliefs. The process of change thus involves a pushing and pulling of the dilemma and a tradition to bring them together. ${ }^{, 46}$ It will be argued below that the judicial activity as regards the IPP sentence exemplifies exactly this tension, as actors sought to make congruent their understanding of, and response to, conflicting beliefs engaged by dilemmas which they faced.

\section{Methodology}

\footnotetext{
${ }^{37}$ Bevir, op. cit. n.7, p. 58.

${ }^{38}$ Bevir and Rhodes, op. cit. n. 5, p. 36.

${ }^{39}$ id.

${ }^{40}$ Bevir and Rhodes, op. cit. n. 27, p. 9.

${ }^{41}$ C. Hay, Political Analysis (2002) ch. 6.

42 id., ch. 6.

${ }^{43}$ Bevir and Rhodes, op. cit. n. 5, pp. 36-7.

${ }^{44}$ Paterson, op. cit. n. 2, p. 8.

${ }^{45}$ Bevir and Rhodes, op. cit. n. 5, p. 37.

${ }^{46} \mathrm{id}$., emphasis added.
} 
The case study set out below is informed by analysis of relevant documents including legal judgments, judicial speeches and articles and other relevant contextual material (including speeches made at Chatham House rules events, legal and academic discussion of the relevant judgments and relevant newspaper articles). Given its underpinning assumptions, an interpretive approach sees great value in ethnographic or interview-based methods that enable the researcher to understand developments from the perspective of the research subjects. Therefore, and more unusually, the present article also draws on semi-structured interviews conducted with five relevant serving or retired senior judges.

The term 'senior judge' is used to denote those judges who serve, or have served, in the Court of Appeal or House of Lords/Supreme Court. Often, such judges also hold important 'policy' roles within the judiciary, heading Committees, Commissions and so on. Ethical assurances provided to respondents preclude a more detailed discussion of their roles in relation to the IPP case law, though it can be noted that they were identified by the researcher, and recognised themselves, as being relevant to this research. The sources of quotes presented below are distinguished by reference to 'Senior Judge 1', 'Senior Judge 2' and so on.

Seven judges were approached, with five positive responses received. One judge interviewed did so explicitly on behalf of himself and two judicial colleagues. While additional interviews would have been desirable, the making of requests ceased when it appeared that, due to policies in place, they would not be accepted and would likely be counter-productive. ${ }^{47}$ The interviews were conducted between December 2010 and June 2011. Interviews lasted between 45 and 90 minutes, with four recorded and then transcribed; handwritten notes were made during the unrecorded interview and subsequently typed up.

Interview requests for serving judges were delivered via the Judicial Office for England and Wales; requests to retired judges were delivered individually. An information sheet making clear the nature of the research project, and that quotes may be used in academic publications, was included with all interview requests and also provided to judges at the beginning of the interview.

The research presented in this article forms part of a larger research project, which explored the creation, amendment, contestation and abolition of the IPP sentence. ${ }^{48}$ For this project 48 research interviews were conducted, in addition to the five noted above. Interviewees included relevant ministers, sentencing officials, Home Office and Ministry of Justice officials, special advisers, interest group representatives, members of the House of Lords and Parole Board representatives. Many of these individuals were well placed to provide insightful comment on the judicial activity discussed herein; quotes from these individuals are included where appropriate.

\section{A SENIOR JUDICIAL TRADITION}

Drawing on the concept of tradition set out above, a senior judicial tradition (SJT) will now be sketched. This SJT denotes a set of beliefs shared by members of the senior judiciary. This

\footnotetext{
${ }^{47}$ In hindsight it appears that such concerns were likely misplaced.

${ }^{48}$ H. Annison, Dangerous Politics (forthcoming); H. Annison, 'Weeding the Garden: The Third Way, the Westminster tradition and Imprisonment for Public Protection' (2014) 18 Theoretical Criminology 38.
} 
'set of connected beliefs ${ }^{49}$ are understood as being fused over time but by no means fixed, widely shared and influential, but not necessarily universal.

It is not argued that there exists, nor should one seek to reify, one monolithic, unchanging judicial tradition. The tradition sketched here relates to the senior judiciary; it is likely that there exist several judicial traditions, perhaps organised loosely around legal specialism or the particular court in which judges sit.

In sketching out the SJT, we can usefully begin with Lord Bingham's depiction of the 'traditionalist view of the judicial role' ${ }^{50}$ It rests 'essentially on three propositions. The first relates to the separation of powers. ${ }^{51}$ It sees 'the task of the judges... [as] only to give effect to the terms of what Parliament has enacted. They have no warrant to vary, add to or subtract from the effect of what Parliament has enacted,' nor to 'give effect to what they may think Parliament would have intended. ${ }^{52}$

The second proposition relates to the non-statutory areas of the law. 'Here the task of the judges is to declare what the common law is, and by implication has always been... Thus the judges are a neutral, colourless, undistorting medium through which the law is transmitted to those bound by it. ${ }^{53}$ On this view, "They are not, save perhaps in a minimal sense, makers of the law'. 54

The third proposition is that 'the authority and standing of the judges depend on their strict adherence to these rules. They enjoy the tenure, the independence and the authority which they do precisely because of the essentially technocratic role which they fulfil. ${ }^{55}$ They have no mandate 'to rule on what would best serve the public interest.

By connecting these propositions to academic commentary we can suggest that the SJT involves a general desire to act 'responsibly', ${ }^{57}$ and thereby a trust in, and desire to shore up, existing administrative and government systems. ${ }^{58}$ The senior judiciary seek to maintain the standing of the senior courts and related institutions ${ }^{59}$ and equate stability with the public interest. ${ }^{60}$ An incrementalist approach is prioritized, ${ }^{61}$ with judges holding a concomitant belief in the 'mirror principle' - that the British courts should keep pace with Strasbourg jurisprudence but not go beyond it. ${ }^{62}$ Encroachment into the 'policymaking' arena is only permitted in exceptional circumstances and explicitly 'political' behaviour is unacceptable. ${ }^{63}$ These features will be discussed in a little more detail, before potentially more 'liberating' aspects of the SJT are noted.

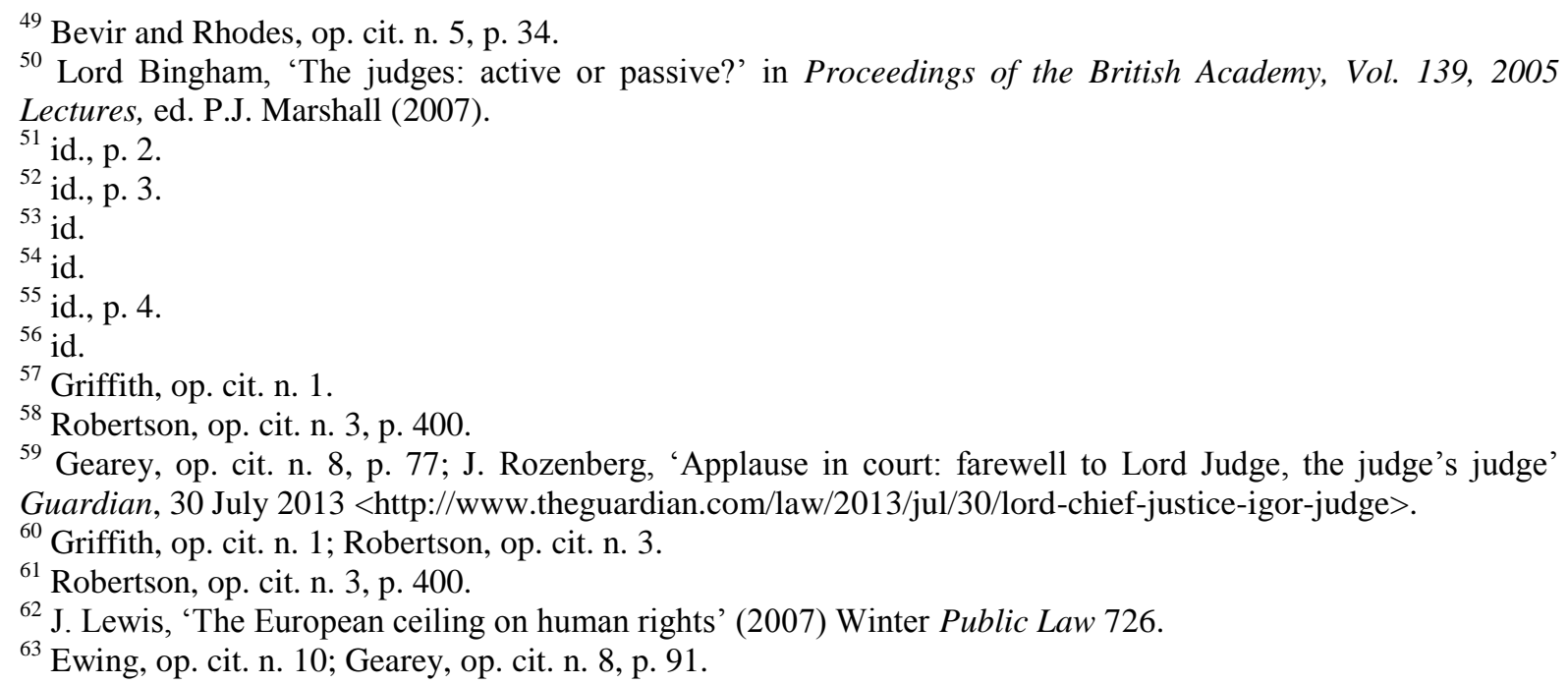


Scholars have identified a persistent belief among the senior judiciary that 'policymaking' is not a legitimate part of judicial activity. The judiciary should, and do, stand above and apart from the political class. ${ }^{64}$ In developing the common law, judges must proceed 'from a baseline of existing principle. ${ }^{65}$ While this process may engage policy considerations, it is widely understood that 'in those cases where the formation of principle involves too great an intrusion into the field of policy, the judge must defer to Parliament. ${ }^{, 66}$

Several reasons are generally given for this deference. Some justify it on the basis of the democratic legitimacy of Parliament, a notion at the heart of the separation of powers doctrine.$^{67}$ As one judge interviewed put it, 'There are discussions. But the judiciary will not advise the government on policy. Because that just ain't our job' (Senior judge 3). Others have suggested that it flows from 'the differentiation of the tasks of the courts and Parliament', with 'independence [making] the courts more suited to deciding some kinds of questions and being elected [making] the legislature or executive more suited to deciding others. ${ }^{, 68}$

Scholars such as Jonathan Lewis have argued that the historically incrementalist approach of the House of Lords has continued, ${ }^{69}$ notwithstanding the introduction of the Human Rights Act $1998 .^{70}$ For Lewis, a 'mirror principle' has developed whereby 'the duty of the national courts is to keep pace with the Strasbourg jurisprudence as it evolves over time: no more, but certainly no less. ${ }^{, 71}$ This has been argued by Keith Ewing to lead to the contradictory position:

\section{adopted by judges who claim or assert power...[while being] simultaneously reluctant to use the powers they already have. A great deal of restraint is to be seen in the approach of the courts to the Human Rights Act. ${ }^{72}$}

However, within these self-imposed boundaries lies a fierce protectiveness of an element which suggests a more 'liberating' understanding of the SJT: 'judicial discretion, with its concomitant principle of judicial independence, is central to the self-concept of the [Anglo-Australian] judiciary. ${ }^{73}$ As David Riesman put it, "many judges resent the straitjacket that codes and legislation seek to impose on their wish to maintain an easy or "muddling through" fluidity. ${ }^{74}$ More recently, Nigel Fielding has similarly identified 'an occupational culture bearing values supporting resistance to outside influence. ${ }^{, 75}$

Fielding found that the British and American judges he interviewed held conventional attitudes regarding a reluctance to engage in policymaking, but "nevertheless testified to activist perspectives that they squarely attributed to feeling obliged to resist a succession of "bad" governments that had legislated "bad law". ${ }^{76}$ Fielding described this as "conservative activism', an effort to resist the outside influences of governments and a public 'convinced

\footnotetext{
${ }^{64}$ N. Lacey, The Prisoners' Dilemma (2008) 96.

${ }^{65}$ McLoughlin v O'Brian [1983] 1 AC 410, per Lord Scarman at para.430. See also Robertson, op. cit. n. 3.

${ }^{66}$ Gearey, op. cit. n. 8, p. 88.

${ }^{67}$ S. Fredman, 'From Deference to Democracy' (2005) 122 Law Q. Rev. 53; A. Kavanagh, 'Judging the Judges under the Human Rights Act' (2009) Public Law 287.

${ }^{68} R$. (on the application of ProLife Alliance) v BBC [2003] UKHL 23, para. 76.

${ }^{69}$ Robertson, op. cit. n. 3.

${ }^{70}$ Lewis, op. cit. n. 62. See also H. Fenwick et al., Judicial Reasoning under the UK Human Rights Act (2011).

${ }^{71} R$ (on the application of Ullah) $v$ Special Adjudicator [2004] UKHL 26; [2004] 2 A.C. 323, para. 20.

${ }^{72}$ Ewing, op. cit. n. 10, p. 268.

${ }^{73}$ A. Freiberg, 'Guerrilas in Our Midst?' in Dangerous Offenders, ed. D. Brown and J. Pratt (2000) 62.

${ }_{75}^{74}$ D. Riesman, 'Law and Sociology' in Abundance for What, and Other Essays, ed. D Riesman (1957) 458-459.

${ }^{75}$ Fielding, op. cit. n. 9, p. 114.

${ }^{76}$ Fielding, op. cit. n. 9 , p. 99.
} 
the judiciary generally gets sentences wrong. ${ }^{, 77}$ Examples abound of judicial efforts to "find ways around' or to correct ill-considered laws made by government. ${ }^{78}$ Pertinent examples include the judiciary's obliteration of the Criminal Justice Act 1991's efforts to remove previous convictions as a sentencing consideration, ${ }^{79}$ and the substantial emasculation of the mandatory sentences contained in the Crime (Sentences) Act $1997 .{ }^{80}$

Such 'activism' was memorably described by Lord Woolf as a valuable central feature of the British common law system:

[It] enables the courts to vary the extent of their intervention to reflect current needs, and by this means it helps to maintain the delicate balance of a democratic society. ${ }^{81}$

Some would go further and suggest that any accurate conception of a SJT must include not only a belief in the value of judicial discretion, but also support for 'fundamental principles and approaches of the common law...in particular proportionality, discretion and natural justice. ${ }^{, 82}$ For example, Arie Freiberg has argued that, 'Consciously or unconsciously, Anglo-Australian judges have been steeped in the principles of classical jurisprudence. ${ }^{, 83}$

However, various scholars have argued convincingly that the incoherent and eclectic use of competing philosophies of punishment by the British judiciary demonstrates that any apparent prioritization of a particular sentencing goal is more accurately understood as an artefact of post hoc rationalization. ${ }^{84}$ We might therefore suggest that the SJT does not include settled endorsement of a particular sentencing principle, but rather involves a belief in the legitimacy of an ad hoc, case-by-case prioritization supportive of a fluidity which supports the realization of justice in individual cases.

This sketch is not intended as an encyclopaedic definition of a fixed entity, but rather a pragmatic description of a set of connected beliefs which most members of the senior judiciary might recognise as underpinning their activity. ${ }^{85}$ With this judicial tradition sketched, the key legal judgments relating to the IPP sentence will now be explored.

\section{CASE STUDY: THE IMPRISONMENT FOR PUBLIC PROTECTION CASE LAW AND JUDICIAL POLITICS}

The Imprisonment for Public Protection (IPP) sentence constituted the headline provision of a new sentencing regime for 'dangerous offenders' introduced by the Criminal Justice Act (CJA) 2003. The legislation provided a framework whereby those deemed to pose a 'significant risk to members of the public of serious harm' ${ }^{86}$ would be liable either to

\footnotetext{
${ }^{77}$ Fielding, op. cit. n. 9, p. 114. This is not to say that judges self-identify as 'activist'.

${ }^{78}$ Fielding, op. cit. n. 9, p. 110.

${ }^{79}$ M. Cavadino and J. Dignan, The Penal System: An introduction (2007) 114-115, 374-375.

${ }^{80}$ T. Jones and T. Newburn, 'Three Strikes and You're Out: Exploring Symbol and Substance in American and British Crime Control Politics' (2006) 46 Brit. J. of Criminology 5.

${ }^{81}$ L. Woolf, 'Droit Public - English Style' (1995) Public Law 57.

${ }^{82}$ Freiberg, op. cit. n. 73, p. 66.

${ }^{83}$ Freiberg, op. cit. n. 73 , p. 58.

${ }^{84}$ See L. Zedner, Criminal Justice (2004) 181; A. Ashworth, Sentencing and Criminal Justice (2010), ch. 3; Robertson, op. cit. n. 3, p. 385.

${ }^{85}$ Bevir and Rhodes, op. cit. n. 5, p. 33-4.

${ }^{86}$ Section 229(1) CJA 2003.
} 
imprisonment for life, imprisonment for public protection, or an extended sentence. ${ }^{87}$ Initially, if the defendant met the statutory conditions, imposition of an IPP sentence was mandatory. Vastly expanding the scope of indeterminate sentences, over 6,500 IPP sentences had been imposed by 31 March $2012{ }^{88}$ This has contributed to a fundamental change in the nature of the prison population, with one in five prisoners now serving indeterminate sentences. ${ }^{89}$ Subsequently amended by the Criminal Justice and Immigration Act 2008, its effects reverberate still, long after its abolition by the Legal Aid, Sentencing and Punishment of Offenders Act 2012..$^{90}$

\section{Judicial Concerns}

The judiciary's concerns began with the policy process. The relevant White Paper, 'Justice for All', ${ }^{91}$ gave only a limited indication of the likely nature and potential impact of what would become the IPP sentence. As the Parliamentary stages of the Criminal Justice Bill neared in November 2002, more detailed proposals were provided to relevant bodies such as the Sentencing Guidelines Council and the Council of Circuit Judges, but only at a very late stage. ${ }^{92}$ It was clear that this was in no way a consultative exercise: 'These were not provisions that were going to be resiled from' (Home Office official).

Then Home Secretary David Blunkett's distrust of the senior judiciary was made clear in February 2003, when the trial judge's freedom to decide whether the imposition of an IPP was appropriate was further restricted by a revision to the relevant clauses of the Bill. This was justified, in Prisons minister Hilary Benn's characteristically under-stated manner, on the basis that an absence of heavy restrictions on judicial discretion 'could undermine the purpose of the new provisions. ${ }^{93}$ The government's actions suggested that the judiciary were perceived as troublesome 'guerrillas in their midst." ${ }^{94}$

On 26 April 2005, three weeks after the implementation of the dangerous offender provisions, members of the senior judiciary took the unusual step of making public their concerns at specific legislative provisions:

The judges, speaking to The Guardian on condition of anonymity, fear the Criminal Justice Act 2003 could lead to an explosion in the prison population and that mandatory measures could force them to impose sentences which are unfair in all the circumstances of the case. $^{95}$

In exploring the reasons for such deep concern, one senior judge interviewed recalled that central to many judges' thinking was:

${ }^{87}$ These sentences replaced the automatic life sentence; longer than proportionate sentences for sexual and violent offenders; extended sentences; and to a large extent the discretionary sentence of life imprisonment: Ashworth, op. cit. n.84, pp. 209-212.

${ }^{88}$ Prison Reform Trust, Bromley Briefings Prison Factfile: November 2012 (2012) 21.

${ }^{89}$ id.

${ }^{90}$ Howard League for Penal Reform, The Never-Ending Story (2013).

${ }^{91}$ Home Office, Justice for All (2002; Cm. 5563) 95-96.

${ }^{92}$ Research interviews, Home Office officials.

${ }^{93}$ Hilary Benn MP, Hansard HC Standing Committee B col 936 (11 February 2003).

${ }^{94}$ Freiberg, op. cit. n. 73; On the battles between David Blunkett and the senior judiciary, see R. Stevens, The English Judges (2002) 129-136.

${ }^{95}$ C. Dyer, "Judges speak out against erosion of independence by government," The Guardian, 26 April 2005. 
the old concept of retribution...there's got to be a degree of fairness, of proportionality in Human Rights Act terms between the sentence which is passed and what has been done (Senior judge 1).

Another senior judge noted that:

I think that was a sort of cultural thing in a sort of way, I don't think we have ever felt very comfortable with the idea that you're punishing somebody for what they might do, as opposed to what they have done. We were all brought up, so to speak, in the "just deserts" sort of school of punishment. You only reserve a sentence which is there for protection of the public for those who've done something really serious. Which, in other words, justifies the life sentences. And I think we all felt more comfortable with that sort of regime than we did in the first instance being made to impose an IPP (Senior judge 2). ${ }^{96}$

The recollections of one judge reflect in part an inclination towards a 'classical' sentencing philosophy, ${ }^{97}$ but more broadly his concerns regarding the potential for unfairness:

Taken at its face, the assumptions of "dangerousness" contained within the Act as originally passed made it difficult for a judge seeking honestly to construe the legislation - to avoid making the presumption [that the defendant was dangerous] in cases where an indeterminate sentence would never have been considered. And this caused us a real problem, because there is a dichotomy between the principles of punishment - on the one hand a retributive view which could be interpreted as Nigel Walker, Professor of the Institute of Criminology, would have interpreted it as "distributive retributivism". ${ }^{98}$ No more than an eye for an eye, and no more than a tooth for a tooth, [and this was] giving way to a utilitarian view of punishment, that the greater good of society was served by ensuring that those whom society deemed dangerous were locked up until they weren't dangerous. Almost irrespective of what they'd done (Senior judge 3).

Given the potential imposition of severely disproportionate sentences, the senior judiciary were clear that the restriction of judicial discretion was of as much, if not more, concern than the nature of the sentence itself. ${ }^{99}$ Judicial discretion was seen as the essential means by which the potential injustices brought about by the IPP sentence might be obviated:

It's a question of where you draw the line. I have no difficulty with the principle [of prevention]. If there is developing knowledge - I'm always...[sceptical] about psychiatrists and psychologists, but - I'm perfectly happy to accept that if there is sensible research that shows, for want of a better phrase, that it's possible to predict with a reasonable degree of accuracy that [an individual], at any rate for the

\footnotetext{
${ }^{96}$ The judge is speaking to the period 2005-8, before the extent of judicial discretion was increased.

${ }^{97}$ Freiberg, op. cit. n. 73.

${ }^{98}$ The judge interviewed is conflating two related approaches to retribution: the 'limiting' retributivist 'does not insist that the severity of the penalty should match the offender's culpability; only that it should not exceed what would match it'. The 'distributive' view, on the other hand, insists on the principle 'no penalty without culpability': N. Walker, Punishment, Danger and Stigma (1980) 25-26. Nigel Walker served as Wolfson Professor of Criminology at the Institute of Criminology, University of Cambridge, from 1973 to 1984.

99 See also Lord Phillips of Worth Matravers, 'Who Decides the Sentence?' <http://www.prisonerseducation.org.uk/index.php?id=211> and Attorney's Reference (No 55 of 2008) [2008] EWCA Crim 2790.
} 
next ten years, is likely to be causing problems, well, then fine. The judges ought to be able to have access to that material and use those tools. But at the end of the day, what I do resist is judges being put in straitjackets, which produces injustice in particular cases (Senior judge 1, emphasis added).

The 'attempt to tie the judiciary down' in relation to sentencing was reflected on by another senior judge as 'an ongoing, and great problem' (Senior judge 5). ${ }^{100}$

Finally, there was also anxiety about what these sentencing changes would mean for the prison population, ${ }^{101}$ with lectures from David Thomas at Judicial Studies Board seminars making it 'obvious to all that the provisions, if applied literally, would result in thousands of offenders being given indeterminate sentences in circumstances where their offence or conviction would make that hard to justify on any common sense basis." ${ }^{102}$ This was the 'real overriding concern...just entirely unsustainable' (Senior judge 5).

From its inception, the systems of rehabilitation and parole required by the IPP sentence were significantly under-resourced, ${ }^{103}$ which along with the risk-averse political rhetoric surrounding the sentence contributed to a substantial increase in IPP prisoners. The number of IPP prisoners rose swiftly from 1,079 in June 2006 to 4,461 in June 2008 and 5,828 in January 2010. ${ }^{104}$ IPP prisoners found themselves at the end of their tariff period, but unable to demonstrate that they no longer represented a risk to members of the public. They often found themselves unable even to obtain a timely Parole Board hearing in which to argue their case. ${ }^{105}$ In short, the senior judiciary's worst fears were being borne out.

This 'lamentable state of affairs" ${ }^{106}$ was heavily criticised both in legal judgments and public speeches. ${ }^{107}$ The consequence of the under-funding was described by the notably outspoken Lord Justice Laws thus: 'the prison population is swollen by persons whose incarceration retributive justice does not require and whose release executive management does not allow. ${ }^{, 108}$ If the Home Secretary considered the senior judiciary to be irresponsible, there were ample reasons for the feeling to be mutual. ${ }^{109}$

\section{The Judiciary Respond}

The introduction of the IPP sentence, and the resulting systemic problems, led to several high-profile cases. The resulting judgments centred on two issues: first, the meaning and scope of the IPP provisions and second, the lawfulness of the post-tariff detention of IPP prisoners in a context where the IPP system was suffering from severe under-resourcing.

\footnotetext{
${ }^{100}$ A. Ashworth, 'The Struggle for Supremacy in Sentencing' in Sentencing Guidelines: Exploring the English model, ed. A. Ashworth and J.V. Roberts (2013).

${ }^{101} R v$ Lang et al [2005] EWCA Crim 2864, para. 16.

${ }^{102}$ M. Wasik, 'The Test for Dangerousness' in Seeking Security, ed. I. Dennis and G. Sullivan (2012) 245.

${ }^{103}$ HM Chief Inspectors of Prisons and Probation, The Indeterminate Sentence for Public Protection: A Thematic Review (2008).

${ }^{104}$ J. Jacobson and M. Hough, Unjust Deserts (2010) 12.

${ }^{105}$ HM Chief Inspectors of Prisons and Probation, op. cit. n. 103.

${ }^{106}$ R. (Wells) v Parole Board; R. (Walker) v Secretary of State for the Home Department [2007] EWHC 1835; [2008] 1 All ER 138, para. 30.

${ }^{107}$ Lord Phillips, op. cit. n. 99.

108 R. (Walker) v Secretary of State for Justice (Parole Board intervening); R. (James) v Same (Same intervening) [2008] EWCA Civ 30; [2008] 1 WLR 1977, para. 20, quoting Wells [2007] EWHC 1835, para. 31.

${ }^{109}$ Stevens, op. cit. n. 94, ch. 9.
} 


\section{(a) Interpreting the Legislative Provisions}

The case of Lang $^{110}$ constituted the Court of Appeal's first opportunity to provide guidance to courts on the 'dangerous offender' provisions of the CJA 2003. The judgment, heard on 3 November 2005, brought together 13 separate cases, where, in all but one, sentences of life imprisonment; imprisonment or detention for public protection; ${ }^{111}$ or extended sentences, had been imposed. ${ }^{112}$

The judgment of the court was delivered by Lord Justice Rose. It was cast as 'merely an attempt to summarise the approach to sentencing which the Act requires and to give guidance as to its meaning. ${ }^{, 13}$ However, commentators and judges alike were in no doubt that the judgment constituted an effort to 'talk down' the use of the sentence, advancing a limited interpretation of the provisions which arguably constituted an attempt to rebut the fundamental premise of the IPP sentence and to reshape it accordingly. ${ }^{114}$

Lord Justice Rose was renowned both for his criticism of the CJA 2003 and his propensity, as one judge put it, 'to stretch the principles of statutory interpretation to the limit' (Senior judge 4). His approach was no different in the present case. For example, Rose LJ emphasized that in relation to the identification of a 'significant risk of serious harm', 'significant' should be taken to mean 'of considerable amount...or importance. ${ }^{115}$ Further, where the anticipated future offence is not serious, 'there will be comparatively few cases in which a risk of serious harm will properly be regarded as significant. ${ }^{116}$

Notwithstanding the restrictive wording of the IPP sentence, Lord Justice Rose stressed the importance of judicial discretion. Casting its exercise as 'historically, at the very heart of judicial sentencing, ${ }^{117}$ Lord Justice Rose stated that 'the language of the statute indicates that judges are expected, albeit starting from the assumption [that offenders falling within the provisions' scope are "dangerous"], to exercise their ability to reach a reasonable conclusion in the light of the information before them. ${ }^{118}$ Therefore:

In our judgment, when sections 229 and 224 of the [2003 Criminal Justice] Act are read together, unless the information about offences, pattern of behaviour and the offender (to which regard must be paid under section 229(3) of the Act) show a significant risk of serious harm (defined by section 224 of the Act as death or serious injury) from further offences, it will usually be unreasonable to conclude that the assumption applies. ${ }^{119}$

\footnotetext{
${ }^{110}$ Lang et al, op. cit. n. 101.

${ }^{111}$ It will be recalled that a sentence of 'detention for public protection' was created for those under 18 years of age by s226 Criminal Justice Act 2003.

112 The thirteenth case involved a suspended sentence of detention in a young offender institution.

${ }^{113}$ Lang et al, op. cit. n. 101, para. 4.

${ }^{114}$ D. Thomas, 'Sentencing: Imprisonment for Public Protection - significant risk of serious harm' (2006) April Criminal Law Rev., 359; Wasik, op. cit. n. 102; Research interviews, Senior judges and sentencing officials.

${ }^{115}$ Lang et al, op. cit. n. 101, para. 17.

116 id., para. 17(iv).

117 id., para. $17(\mathrm{v})$.

118 id.

${ }^{119}$ Lang et al, op. cit. n. 101, para. 15, emphasis added.
} 
Faced with the threat of the penal system being inundated with indeterminate IPP prisoners as a consequence of these 'labyrinthine' provisions, ${ }^{120}$ Rose LJ did not hesitate to react.

Renowned sentencing academic David Thomas described it as an 'important judgment' and a 'welcome indication that sentencers should take a restrained and careful approach to making the finding of a significant risk of serious harm. ${ }^{121}$ One judge recalled that, while Lord Justice Rose was somewhat 'pushing the envelope in Lang' (Senior judge 3), it was a positive development because

what Lang did was provide judges with an additional element of discretion, to seek to filter out those cases which truly did not justify the very, very serious sanction that IPP constitutes. Because what a number of us - I'm sure all judges - readily appreciated, was that Imprisonment for Public Protection was as near to a life sentence as it is possible to get (Senior judge 3).

As another judge approvingly recalled,

to some extent, the Vice President Lord Justice Rose was...pushing out the boundaries within which the exercise of discretion was appropriate by saying that 'exceptional' actually meant... 'if it didn't dot every "i" and cross every " $t$ " then it could be exceptional'. Whereas you and I could discuss what that word means as a matter of English and reach a different conclusion. So, had it not been for Lang I have absolutely no doubt that many more sentences of Imprisonment for Public Protection would have been passed (Senior judge 4).

Subsequent to Lang, the Court of Appeal, in judgments such as Johnson ${ }^{122}$ and Isa, ${ }^{123}$ re-iterated the restrictive interpretation of the IPP sentence. These cases served 'to amplify and clarify the guidance given in Lang, rather than to qualify it, ${ }^{124}$ as one judge explained:

[We] took it further in a series of cases where we refined Lang in a sense, and made it plain, you know, that there is a purpose behind this legislation and if this particular case or the person in front of you doesn't really fall into the category of those for whom Parliament must have intended this you don't, you don't say he's dangerous, or you try and avoid saying he's dangerous (Senior judge 2).

Despite these efforts, concerns persisted that trial judges were continuing to overutilize the 'Dangerous Offender' provisions. In a speech given to the All-Party Parliamentary Group on Penal Affairs on 28 March 2006, the Lord Chief Justice, Lord Phillips, chose the IPP sentence as his central topic. He noted that 'sentencers were imposing sentences of IPP for comparatively trivial offences - I heard of one where the sentence was as short as two months. ${ }^{125} \mathrm{He}$ also reiterated judicial concerns with the potential 'pressures that the new regime is going to place on both the parole board and the probation service ${ }^{, 126}$ and the

\footnotetext{
120 id., para. 153.

${ }^{121}$ D. Thomas, 'Sentencing: Dangerous Offenders - Criminal Justice Act 2003' (2006) February Criminal Law Rev. 174, p. 179.

${ }^{122}$ R. v Johnson (Paul Anthony) [2006] EWCA Crim 2486; [2007] 1 W.L.R. 585 (CA (Crim Div)).

${ }^{123}$ R. v Isa (Mustapha Abdi) [2005] EWCA Crim 3330; [2006] 2 Cr. App. R. (S.) 29 (CA (Crim Div)).

${ }^{124}$ D. Thomas, 'Sentencing: Imprisonment for Public Protection - significant risk of serious harm' (2007) Feb Criminal Law Rev., 180; Thomas, op. cit. n. 114.

${ }^{125}$ All-Party Parliamentary Group on Penal Affairs, Crises in Criminal Justice (2007) 13

${ }^{126} \mathrm{id}$.
} 
potential for 'capacity problems in the prisons and [resultant] serious disciplinary problems for those who run the prisons. ${ }^{127}$

With the IPP sentence continuing to cause disquiet, in September 2007 the Sentencing Guidelines Council took the exceptional step of publishing a 'guide', rather than the usual 'guidelines', entitled 'Dangerous Offenders: A Guide for Sentencers and Practitioners'. ${ }^{128}$

The possibility of issuing guidelines in relation to the 'Dangerous Offender' provisions of the CJA 2003 had been discussed by members of the Sentencing Guidelines Council and Home Office officials in December 2004, before the provisions came into force. ${ }^{129}$ However, a different path was chosen:

[Lord Justice] Rose was deputy chairman of the [Sentencing Guidelines] Council, obviously the leading judge on sentencing issues. The great advantage of the Court of Appeal compared with the Council is that it can act much more quickly where something is needed. So in the end, the judgment was that it was going to be much easier and better for the Court of Appeal to pull together some cases and issue some guidance, guidelines, whatever you call them. Which they did initially in Lang and then in the cases that followed. (Sentencing official)

A well-placed civil servant recalled the political nature of the document's creation:

When we were drafting the document we worked closely with the policy officials who were involved in handling the policy aspects of the problems of the legislation. And they would have taken soundings from ministers. But we were just bringing together what already existed, rather than creating something new. So there wouldn't have been any benefit in doing any sort of formal consultation (Sentencing official).

Taken as a whole, these activities suggest that relevant members of the senior judiciary are careful and considered policymakers. The Lord Chief Justice used public speeches to maintain pressure on the government to recognise and address the problems posed by the IPP sentence, while Lang and subsequent judgments sought to promote a restrained reading of the IPP sentence in law.

Applying the interpretive terminology set out above, we can suggest that the dilemmas presented by the IPP sentence posed an important question to relevant members of the senior judiciary: was it legitimate, within the SJT as generally understood, to seek to restrain the application of the IPP sentence and its effects in the ways set out above? The following quote apparently provides a straightforward response:

Parliament are entitled to require us to alter our approach. That's what legislation does in every single field. It provides a steer to the exercise of discretion (Senior judge 3).

However, this apparently clear 'rule' is open to a more expansive interpretation:

If the legislation allows one result which is draconian, will fill the prisons with no very good reason and another interpretation, perfectly

\footnotetext{
127 id.

128 Sentencing Guidelines Council, Dangerous Offenders: Guide for Sentencers and Practitioners (version 1) (2007).

${ }^{129}$ Research interviews, Sentencing Officials.
} 
legitimately, produces a less draconian result but nonetheless provides protection for the public in the most serious cases, then the judges are entitled to follow that course. And, over a period of time, if Parliament don't like what's happened then they can do something about it (Senior judge 1). ${ }^{130}$

The judicial activity surveyed above suggests that the efforts to restrain the IPP sentence were very much understood to be legitimate, according with the SJT as commonly understood.

\section{(b) Post-Tariff Detention of IPP Prisoners}

The key judicial review judgments relating to the legality of the post-tariff detention of IPP prisoners are Wells (High Court), ${ }^{131}$ Walker and Wells (Court of Appeal), ${ }^{132}$ and James, Lee and Wells (House of Lords). ${ }^{133}$ Wells was heard on 22 June 2007. The case was brought by two IPP prisoners, one held beyond tariff and one approaching that point in time.

Three legal arguments were put before Lord Justice Laws and Justice Mitting in the High Court. ${ }^{134}$ The first was based on the common law concept of 'irrationality', or 'Wednesbury unreasonableness': ${ }^{\prime}$ the Secretary of State's failure to properly resource the system for IPP prisoners constituted 'a course of action so unreasonable that the court should condemn it as unlawful. ${ }^{136}$ This lack of adequate resourcing (and resultant difficulties in obtaining timely Parole Board hearings) was also argued to result in the breach of the claimants' Article 5(1) and 5(4) European Convention of Human Rights (ECHR) rights. A finding of a breach of Article 5 would have signalled the unlawfulness of the claimant prisoners' detention and entitled the claimants to compensation. ${ }^{137}$ Further, such a judgment would have inflicted severe political damage on the Secretary of State for Justice and the government of the day.

Lord Justice Laws recognised a clear difficulty for the claimants, namely that it is well settled that the courts are generally in no position to make judgments upon competing claims for the allocation of scarce public resources, and will decline to do so. ${ }^{138}$ However, he argued that the "correct outcome of these proceedings...lies in deeper considerations. ${ }^{139}$ For while,

both elements - the whole sentence - are formally justified by the order of the sentencing court...the justification that is required for [the prisoner's] detention after the tariff's expiry...is of an altogether different character. This further detention is not at all justified by or at the time of sentence, for the very reason that the extent to which, or the time for which, the prisoner will remain a danger is unknown

\footnotetext{
${ }^{130}$ Senior judge 1 went on in the interview to agree with the position set out by Senior judge 3 .

${ }^{131}$ Wells, op. cit. n. 106.

132 Walker and James, op. cit. n. 108.

${ }^{133} R$. (James) v Secretary of State for Justice (Parole Board intervening); R. (Lee) v Same (Same intervening); $R$. (Wells) v Same (Same intervening) [2009] UKHL 22; [2009] 2 WLR 1149.

${ }_{134}$ Laws LJ gave the only reasoned judgment.

${ }^{135}$ Associated Provincial Picture Houses Ltd v Wednesbury Corp [1947] 2 All ER 680.

${ }^{136}$ Wells, op. cit. n. 106, para. 38.

${ }^{137}$ For discussion of Article 5 ECHR see D. J. Harris et al., Law of the European Convention on Human Rights (2009) chapter 5.

${ }^{138}$ Wells, op. cit. n. 106, para. 39.

139 id., para. 44.
} 
at the time of sentence. It can only be ascertained on a continuing basis, by periodic assessment. ${ }^{140}$

It was 'a straightforward point of law' that:

Without current and periodic means of assessing the prisoner's risk the regime cannot work as Parliament intended, and the only possible justification for the prisoner's further detention is altogether absent. In that case the detention is arbitrary and unreasonable on first principles, and therefore unlawful. ${ }^{141}$

Lord Justice Laws has garnered a reputation for 'judicial evangelism'. ${ }^{142} \mathrm{He}$ has argued, for example, that embedded in Britain's constitution is 'the imperative of democracy itself and those [fundamental] rights... which cannot be denied save by a plea of guilty to totalitarianism'. ${ }^{143}$ This belief in fundamental rights is reflected in the Wells judgment, seen for example in the assertion that:

Whether or not the prisoner ceases to present a danger cannot be a neutral consideration, in statute or policy. If it were, we would forego any claim to a rational and humane (and efficient) prison regime. ${ }^{144}$

For Laws LJ, the 'imperative that treats imprisonment strictly and always as a last resort ${ }^{145}$ must be recognised. This was the foundational principle which supported the understanding:

that government would provide offending behaviour courses and the like so as to enable lifers to be released at or as soon as possible after tariff expiry where the risk they posed at that stage could be shown to be low enough for that to be justified. ${ }^{146}$

The Wells judgment constituted a strident attack on the failures of the IPP sentence, and on a government that had shown itself incapable of adequately implementing its own policies and, thereby, upholding prisoners' basic rights. ${ }^{147}$ Laws LJ appears mindful of the SJT, careful to couch his judgment not as a discussion of 'the wisdom or practicality of this or that use of scarce resources', but as 'a straightforward point of law.' ${ }^{148}$ However, the judgment clearly demonstrates Laws LJ's beliefs and his desire to apply pressure to a government of whom the judiciary appeared to despair.

In a subsequent claim for judicial review by an IPP prisoner held beyond tariff heard on 20 August 2007, ${ }^{149}$ Justice Collins followed Lord Justice Laws' reasoning, directing the claimant prisoner's immediate release. However, the prisoner's release was stayed, pending a combined appeal to the Court of Appeal. In a passage which could not avoid causing alarm to the Ministry of Justice, Justice Collins noted that, if Laws LJ's analysis was correct,

\footnotetext{
140 id., para. 45-46.

141 id., para. 48

${ }^{142}$ Griffith, op. cit. n. 1, p. 333.

143 J. Laws, 'Law and Democracy' (1995) Public Law 92; J. A. G. Griffith, 'The Brave New World of Sir John Laws' (2000) 63 The Modern Law Rev. 2.

${ }^{144}$ Wells, op. cit. n. 106, para. 49, emphasis added.

145 id., para. 49.

146 id., para. 24, emphasis added.

147 HM Chief Inspectors of Prisons and Probation, op. cit. n. 103; Howard League for Penal Reform, Indeterminate Sentences for Public Protection (2007); Prison Reform Trust, Indefinitely Maybe? (2007).

${ }^{148}$ Wells, op. cit. n. 106, para. 48.

${ }^{149} R$. (James) v Secretary of State for Justice [2007] EWHC 2027 (Admin).
} 
the consequences are truly, in one sense, disastrous, because I think it is inevitable logic following from what Laws LJ has indicated that a prisoner such as the claimant... will have to be released whether or not he remains a risk to the public. ${ }^{150}$

The policy concerns that underpinned the Wells judgment were reiterated by then President of the Queen's Bench Division Sir Igor Judge on 3 July 2007, several weeks before Laws LJ delivered his judgment. Speaking to the Justice Committee, he observed that:

By the year 2012 the Home Office statistics estimate we will have 25,000 of these [IPP] prisoners. We think - and we are only guessing - that for the judges to be available to consider the parole reports...the Parole Board will need some 100 extra judges. Where will they come from? Where will these 25,000 be kept in custody? What effect will this have on the prison population? It is for Parliament to say. I am merely pointing out that the IPP has already had and will continue to have an extraordinary effect on prison populations. ${ }^{151}$

In response to the above judgments and growing criticism of the IPP sentence, ${ }^{152}$ the government revealed that amendments to the IPP were being formulated. These were said to involve the introduction of a minimum tariff, an increase in judicial discretion, and the provision of additional resources for prisoner training courses. ${ }^{153}$

The combined appeal from Wells and James was heard by the Court of Appeal in November 2007, with then Lord Chief Justice, Lord Phillips of Worth Matravers, delivering judgment on 1 February 2008. Surveying 'an unhappy state of affairs', ${ }^{154}$ the court upheld Lord Justice Laws' finding that the Secretary of State's failure to resource adequately the Prison Service and Parole Board so as to enable the Dangerous Offender provision of the CJA 2003 to operate as intended was unlawful. Lord Phillips stated that:

We are satisfied that [the Secretary of State's] conduct has been in breach of his public law duty because its direct and natural consequence is to make it likely that a proportion of IPP prisoners will, avoidably, be kept in prison for longer than necessary either for punishment or for protection of the public, contrary to the intention of Parliament (and the objective of article 5 [ECHR] to which Parliament must have been mindful). ${ }^{155}$

The judgment was predicated on the view that the government's failure as regards resourcing meant that IPP prisoners were not being provided with a 'fair chance of ceasing to be, and showing that they had ceased to be, dangerous. ${ }^{156}$ Lord Phillips concurred with Lord Justice Laws' statement that the rehabilitation of IPP prisoners was a 'premise of the legislation. ${ }^{, 157}$ On this basis, Lord Phillips deplored the

\footnotetext{
150 id., para. 10.

151 Justice Committee, Towards Effective Sentencing: Oral and Written Evidence Volume II (2008, HC 184-II). Q198.

${ }^{152}$ HM Chief Inspectors of Prisons and Probation, op. cit. n. 103; Howard League for Penal Reform, op. cit. n. 147; Prison Reform Trust, Indefinitely Maybe? (2007).

${ }^{153}$ Lord Carter of Coles, Securing the Future: Proposals for the efficient and sustainable use of custody in England and Wales (2007).

${ }^{154}$ Walker and Wells, op. cit. n. 108.

155 id., para. 40.

156 id., para. 41.

${ }^{157}$ Wells, op. cit. n. 106, para. 26; quoted with approval by Lord Phillips in Walker and Wells, op. cit. n. 108, para. 40.
} 
systemic failure on the part of the Secretary of State to put in place the resources necessary to implement the scheme of rehabilitation necessary to enable the relevant provisions to function as intended. ${ }^{158}$,

However, Lord Phillips concluded that, given the legislation in place (in particular s28 Crime (Sentences) Act 1997 concerning prisoner release), ${ }^{159}$ it was not possible to subscribe to Lord Justice Laws' view of post-tariff IPP prisoners as being 'unlawfully detained' and accordingly ruled that the order for release in James should be set aside. ${ }^{160}$ The appropriate remedy in these circumstances was limited to declaratory relief. ${ }^{161}$

As Patricia Londono noted at the time, this judgment 'could legitimately be characterised as cautious. ${ }^{162}$ Lord Phillips' deep concern at the IPP sentence and its effects is evident, but the judgment was mitigated by the requirement to 'give effect to [the law] Parliament has enacted ${ }^{\prime 163}$ and the judiciary's reluctance to engage in an expansive interpretation of the European Convention of Human Rights ${ }^{164}$ - central features of the SJT. Nonetheless, pressure was maintained by Lord Phillips, who suggested that if the present situation continued, with many Parole Board hearings effectively constituting 'an empty exercise', a breach of Article 5(4) ECHR would likely be found. ${ }^{165}$ Further, it was suggested that while this stage had not yet been reached, the more damaging finding of a government breach of Article 5(1) ECHR may occur,

when the stage is reached that it is no longer necessary for the protection of the public that they should be confined or if so long elapses without a meaningful review of this question that their detention becomes disproportionate or arbitrary. ${ }^{166}$

Lord Phillips went even further, stating that if such problems continued:

There are circumstances in which the Secretary of State can release prisoners before they have served a minimum custodial term...It might be argued that one or other of these powers can and should properly be stretched so as to enable and require the Secretary of State to release a prisoner if his continued detention will infringe article $5(1) .{ }^{167}$

While that question was left 'for another day', ${ }^{168}$ it was a clear signal to the government that a continued failure to address the problems of the IPP sentence would not be tolerated by the senior judiciary. ${ }^{169}$ Lord Phillips' determination to apply pressure to the executive in such instances of government failure has been a feature of his Supreme Court, ${ }^{170}$ and was in evidence here. However, equally evident is the enduring influence of the

\footnotetext{
${ }^{158}$ Walker and Wells, op. cit. n. 108, para. 72.

${ }^{159}$ This provision states, inter alia, that relevant prisoners can only be released once the Parole Board is satisfied that it is no longer necessary for the protection of the public that he or she remain confined.

${ }^{160}$ Walker and Wells, op. cit. n.108, paras. 47, 70.

161 id., para. 72.

162 P. Londono, 'The executive, the Parole Board and article 5 ECHR: Progress within "an unhappy state of affairs"?' (2008) 67(2) Cambridge Law J. 233.

${ }^{163}$ Bingham, op. cit. n. 50, p. 3.

${ }^{164}$ Lewis, op. cit. n. 62.

${ }^{165}$ Walker and Wells, op. cit. n. 108, para. 67. See also Lord Phillips of Worth Matravers, op. cit. n. 99.

166 id., para. 69.

167 id., para. 72

168 id., para. 72

${ }^{169}$ See also Lord Phillips, op. cit. n. 99.

${ }^{170}$ Paterson, op. cit. n. 19.
} 
'traditionalist view of the judicial role ${ }^{, 171}$ and the limitations that it entails. Application for leave to appeal to the House of Lords was made by two of the claimant prisoners, with leave granted by the House of Lords on 15 January 2009.

By the time of the House of Lords' judgment on 6 May 2009, the amendments of the IPP sentence contained within the Criminal Justice and Immigration Act 2008 had been brought into law. The legislation introduced a minimum two-year (four-year determinate equivalent) tariff and increased judicial discretion, while efforts were underway by the Ministry of Justice to expedite IPP prisoners' progress through the penal system. ${ }^{172}$ Then Secretary of State for Justice Jack Straw worked hard to rebuild relationships with the judiciary and to address problems such as those caused by the IPP sentence. ${ }^{173}$

Nonetheless, the Lord Chief Justice made public his concern that there remained,

a substantial number of IPP prisoners sentenced under the old regime, who have served their tariffs but who are faced with difficulty in satisfying the Parole Board that they no longer constitute a risk to the public. ${ }^{174}$

It was in this context that the House of Lords considered the same issues as first set out in Wells, with the Parole Board given leave to intervene in the case as an interested party. Their Lordships agreed with the Court of Appeal that 'the Secretary of State failed deplorably in the public law duty that he must be taken to have accepted when he persuaded Parliament to introduce indeterminate sentences for public protection ('IPPs')' 175 By the time of the judgment this had been expressly accepted by the Secretary of State. ${ }^{176}$

However, the Law Lords concluded that the legislation and case law in place made it impossible to regard post-tariff IPP prisoners as 'unlawfully detained' and, further, compelled a restrictive interpretation of the obligations of the Secretary of State, the Prison Service and the Parole Board as regards IPP prisoners. ${ }^{177}$ Not least amongst these was the recognition that s142(2)(c) Criminal Justice Act 2003 expressly disapplied s142(1) to the 'Dangerous Offender' provisions of the 2003 Act - a fact which the High Court and Court of Appeal were noted to have overlooked. ${ }^{178}$ In other words, the government could not have been clearer in its emphasis that 'the first and obvious purpose of these provisions is the protection of the public from the risks posed by dangerous offenders'; ${ }^{179}$ the reform and rehabilitation of offenders was a secondary consideration, at best.

Accepting that the failure to resource the IPP system adequately had caused substantial delays and other problems for many prisoners, Lord Hope nonetheless stated that,

the failures for which the Secretary of State accepts responsibility, while highly regrettable, cannot be said to have created a breakdown

\footnotetext{
${ }^{171}$ Lord Bingham, op. cit. n. 50.

172 Jacobson and Hough, op. cit. n. 104, p. 10.

173 J. Straw, Last Man Standing (2012) 501-3; Constitutional Affairs Committee, Minutes of Evidence (9 October 2007) Qs 64-71.

${ }^{174}$ Lord Phillips of Worth Matravers, op. cit. n. 99. A total of 43 IPP prisoners had been released on licence by December 2008, with 867 IPP prisoners eligible for release in June 2008 and this number tripling to approximately 2,600 by June 2009: Jacobson and Hough, op. cit. n. 104, p. 14.

${ }^{175}$ James, Lee and Wells, op. cit. n.133, para. 3.

176 id., para. 28.

177 id., paras. 5-6, 21, 36-37, 51, 61-62, 123, 126.

178 id., para. 48 .

${ }^{179}$ id., para. 100.
} 
of [an] extreme kind...The causal link with the [public protection] objectives of the sentencing court has not been broken. ${ }^{180}$

On the same point, Lord Brown built upon Lord Hope's formalistic reading of the relevant law by suggesting that:

To my mind, however, before the causal link could be adjudged broken, the Parole Board would have to have been unable to form any view of dangerousness for a period of years rather than months. It should not, after all, be forgotten that the Act itself provides for two-year intervals between references to the Parole Board. ${ }^{181}$

The court ruled that Article 5(1) ECHR was not breached by the Secretary of State's failure to make adequate provision of training courses, to enable progression through the system and properly resource the Parole Board. However, it was stated that a 'prolonged failure' to enable a prisoner to demonstrate that he was safe for release may breach Article $5(1)$ :

Like Lord Brown, I should not exclude the possibility of an article 5(1) challenge in the case of a prisoner sentenced to IPP and allowed to languish in prison for years without receiving any of the attention which both the policy and the relevant rules, and ultimately common humanity, require. ${ }^{182}$

As regards Article 5(4), it was held that this was concerned with procedure rather than substance. The Parole Board was required by statute to release a prisoner serving an IPP only when satisfied that it was no longer necessary for the protection of the public that he should be so confined, ${ }^{183}$ and it was open to them to decide what, and how much, information is needed to decide on a prisoner's suitability for release. Therefore, notwithstanding the argument that for many IPP prisoners Parole Board hearings constituted an empty exercise, Article 5(4) was not breached. The ECHR jurisprudence did not go so far as to support the claimants' argument and it was for Strasbourg, not the Law Lords, to pursue a more expansive interpretation, if they so wished. ${ }^{184}$ Therefore their Lordships concluded that the Secretary of State had acted unlawfully, but only on the common law ground of 'irrationality'.

The judgments proceeded on the basis that the problems surrounding the IPP sentence were predominantly historical:

deficiencies are, at last, being made good. Speaking very generally, courses and training are available and offenders may take advantage of them. The information being made available to the Parole Board when considering whether the offenders should remain in custody is more extensive and evidence-based, and it can make better informed decisions. ${ }^{185}$

Research conducted by Jacobson and Hough and joint thematic reports by HM Chief Inspectors Prisons and Probation suggests that the Law Lords' judgments constituted an overoptimistic, even complacent, reading of the situation facing IPP prisoners in early $2009 .{ }^{186}$

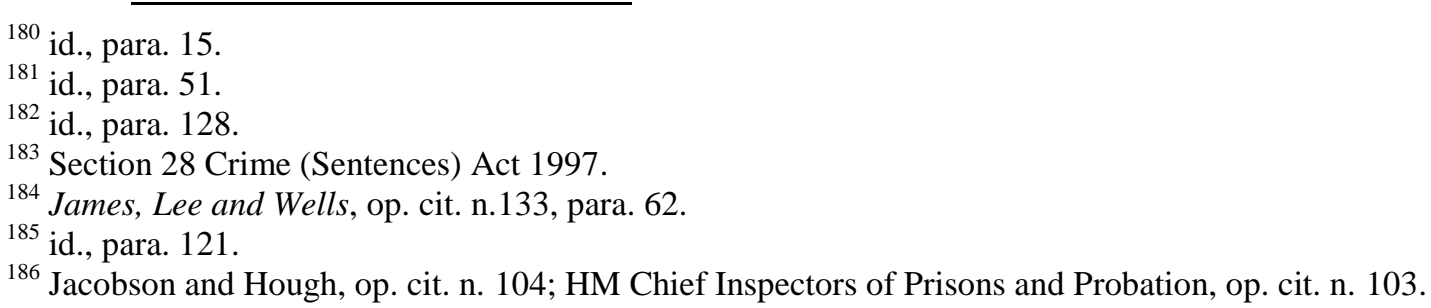


The case subsequently reached Strasbourg. The European Court of Human Rights, in contrast to the House of Lords, concluded that rehabilitation was a central premise of the IPP sentence. ${ }^{187}$ It therefore ruled that the Secretary of State for Justice's failure to adequately resource the systems on which the IPP sentence depended did breach Article 5(1) ECHR. ${ }^{188}$

Considered through an interpretive lens, the House of Lords can be understood to have responded to the dilemma posed by the effects of the IPP sentence with a judgment couched firmly within Lord Bingham's 'traditionalist' understanding of the judicial role. ${ }^{189}$ Their responsibility was 'to give effect to the terms of what Parliament has enacted' 190 and no more. As one judge put it, 'We apply the laws that Parliament has chosen to enact. And we do so because we have taken an oath to uphold the law' (Senior judge 4).

Further insight is provided by consideration of Lord Judge's response to the amendment of the IPP sentence:

[The] statutory assumption of dangerousness in section 229(3) has disappeared. No court will mourn its departure. Its judgment of dangerousness can now be made untrammelled by artificial constraints. That said...[IPP] remains an important sentencing alternative available to the court. ${ }^{191}$

This quote reminds us that members of the judiciary, not least the most senior criminal judge in England and Wales, were not necessarily opposed to the availability of an indeterminate sentence targeted at the 'dangerous'. Indeed, more than one judge described the sentence as 'for some categories of offenders, extremely useful' (Senior judge 2).

In addition, we can note that in a case heard at the same time as Walker and James, ${ }^{192}$ the Court of Appeal considered whether the Parole Board constituted an independent tribunal' for the purposes of Article 5(1) ECHR. ${ }^{193}$ The judgment emphasized the centrality of an independent Parole Board to a just and effective penal system. A ruling by the Court of Appeal or the House of Lords that the IPP sentence was fundamentally unlawful - and potentially that IPP prisoners should be released without assessment by the Parole Board would have conveyed deeply contradictory messages. Considered in the light of the SJT, it would have constituted fundamentally irresponsible activity.

\section{JUDICIAL POLITICS, THE PRE-EMPTIVE TURN AND THE LIMITS OF THE JUDICIAL TRADITION}

The above discussion has explored the nature of judicial activity, specifically by reference to a 'senior judicial tradition'. By tracing the senior judiciary's response to the IPP sentence, we have seen that the senior judiciary are thoughtful participants in a political process, as well as (and simultaneously) conscientious, sincere interpreters of the law.

Judges, as with all political actors, are not captives of their traditions, but strategic actors able to draw on, and potentially re-shape, them as they confront particular dilemmas. The activities of Lord Justice Rose, Laws LJ and Lord Phillips suggest that they were deeply

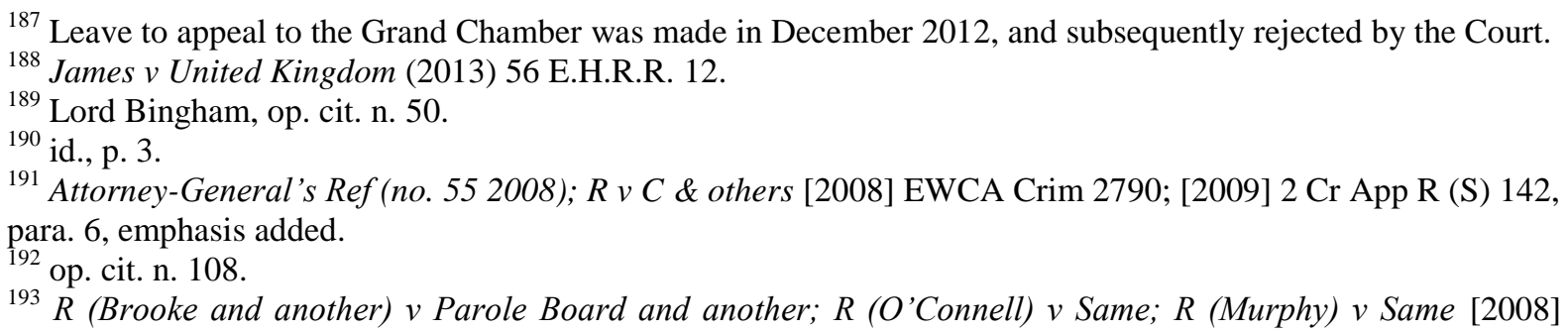
EWCA Civ 29; [2008] 1 WLR 1950. 
concerned by the effects of the IPP sentence but also by its very existence. Lord Judge and some of those interviewed, on the other hand, considered the IPP to remain 'an important sentencing alternative. ${ }^{194}$ The former group appear to have been motivated by those aspects of the SJT which emphasize the value and necessity of proportionality, judicial discretion and the taking of a robust approach to 'bad law'.

However, these aspects were at all stages balanced by a recognition of the centrality of legal formalism and Parliamentary deference, which increasingly came to dominate the substantive legal judgments. Where there is full-frontal assault on the IPP sentence in Wells, ${ }^{195}$ there is a Sword of Damocles in James, Lee and Wells. ${ }^{196}$ The dominant understanding of the SJT resulted in more cautious substantive challenges to the principle and practice of the IPP sentence, although the strength of feeling is revealed by the obiter statements and extra-judicial speeches.

Lord Woolf's important statement, which casts the senior judiciary as a body that seeks to "vary the extent of their intervention to reflect current needs...to maintain the delicate balance of a democratic society, ${ }^{, 197}$ was noted above. This understanding can be seen as central to the senior judiciary's response to the IPP sentence. Alarmed by the reckless policymaking of Home Secretary David Blunkett, the senior judiciary attempted to use relevant judgments, public lectures, Select Committee appearances and anonymous newspaper briefings to ensure that the IPP sentence was put 'back on track'. As the perceived threat declined, the calculations informing their 'delicate balancing' altered, justifying a more limited approach.

The case study provides evidence suggestive of some level of co-ordination of senior judicial interventions. Interviewees did not deny co-ordinating their activity with colleagues, but nor did they present their historical recollections in such terms. Reflection on the above case study, coupled with recognition of the centrality of independence to judicial selfconception and an understanding of the social milieu in which the senior judiciary operate and interact, ${ }^{198}$ would support a conception of judicial political activity as involving what we might term 'measured co-ordination'. This would seem to involve advanced notice of a planned speech or a brief word in a colleague's ear, but likely little more.

In closing, we can note criminal justice scholars' alarm at the increasing centrality of prevention and public protection to sentencing policy and practice. ${ }^{199}$ The IPP sentence can be seen as one of various measures which evidence this 'pre-emptive turn' in sentencing policy, ${ }^{200}$ with state efforts increasingly directed at 'fixing the future' rather than punishing the past. ${ }^{201}$ For liberal legal scholars, these developments pose 'challenges [to] major suppositions of legitimate criminalisation. ${ }^{202}$

The above case study to some extent supports Gearey et al.'s assertion that 'the old stereotypes of a political quiescent or pro status quo judiciary' have broken down over recent decades. ${ }^{203}$ However, we have seen that while the senior judiciary may be political actors, they operate within strict, and largely self-defined, boundaries. The case study presented

\footnotetext{
${ }^{194}$ Attorney-General's Ref (no. 55 2008) op. cit. n. 191.

${ }^{195}$ Wells, op. cit. n. 106.

${ }^{196}$ James, Lee and Wells, op. cit. n. 133.

${ }^{197}$ Woolf, op. cit. n. 81, p. 58.

${ }^{198}$ Paterson, op. cit. n. 2.

${ }^{199}$ Dennis and Sullivan, op. cit. n. 102.

${ }^{200}$ Zedner, op. cit. n. 11.

201 id.; C. Steiker, Limits of the Preventive State (1998).

${ }^{202}$ Dennis and Sullivan, op. cit. n. 102, p. 13.

${ }^{203}$ Gearey, op. cit. n. 8, p. 130.
} 
suggests that the judiciary's rhetorical embrace of 'the significant shift in the judge's own understanding of the role that the judiciary plays in a democratic state', ${ }^{204}$ but reluctance to pursue this to its substantive ends, is an artefact of the nature of the senior judicial tradition and inherent tensions within it.

It is therefore concluded that in a political climate where insecurity and risk aversion have become pervasive and are increasingly instantiated in sentencing provisions, ${ }^{205}$ the dominant understanding of the senior judicial tradition leaves the British senior judiciary illequipped robustly, and in their eyes legitimately, to contest particular instances of the "preemptive turn' in criminal justice. Of course, whether they should do so is another question entirely.

${ }^{204}$ Gearey, op. cit. n. 8, p. 152.

${ }^{205}$ Dennis and Sullivan, op. cit. n. 102. 